\title{
Structural and Production Characteristics of Piatã Grass Forage Submitted to Levels of Nitrogen
}

\author{
Ronaldo Liberato Dourado', Alexandre Lima de Souza ${ }^{2}$, Anderson de Moura Zanine ${ }^{2}$, \\ Fabio Luiz Buranelo Toral ${ }^{3}$, Daniele de Jesus Ferreira' ${ }^{2}$, Joadil Gonçalves de Abreu ${ }^{2}$ \\ ${ }^{1}$ Department of Science and Technology, Federal Institute of Education, Brasilia, Brazil \\ ${ }^{2}$ Department of Animal Science, Federal University of Mato Grosso, Cuiabá, Brazil \\ ${ }^{3}$ Department of Animal Science, Federal University of Minas Gerais, Belo Horizonte, Brazil \\ Email: dany dosanjos@yahoo.com.br, alexandre@ufmt.br, andersonzanine@ufmt.br
}

Received 6 February 2015; accepted 17 March 2015; published 19 March 2015

Copyright (C 2015 by authors and Scientific Research Publishing Inc.

This work is licensed under the Creative Commons Attribution International License (CC BY).

http://creativecommons.org/licenses/by/4.0/

c) (i) Open Access

\begin{abstract}
Piatã grass (Brachiaria brizantha cv. Piatã) is a tropical grass cultivating in pasture production system. The aim of this study was to evaluate the effects of nitrogen levels $(0,125,250,375$ and $500 \mathrm{~kg} \cdot \mathrm{N} \cdot \mathrm{ha}^{-1}$ ) on structural characteristics and forage production of Piatã grass. The experiment comprised of twenty grass parcels arranged in randomised completely casualties design. This study was carried out between November of 2007 and April of 2008, with 175 experimental days. A quadratic effect $(P<0.05)$ was verified for nitrogen dosage on canopy height, final leaf blade length and leaf area index. Nitrogen fertilisation altered the population density of tillers, with estimated maximum value of 955 tillers $\cdot \mathrm{m}^{-2}$ at a nitrogen dose of $357 \mathrm{~kg} \cdot \mathrm{ha}^{-1}$. A quadratic effect $(\mathrm{P}<$ 0.05) was also verified for nitrogen levels on the production of total and green leaf blade dry matter, with estimated maximum values of 19,253 and 11,548 kg ha $^{-1} \cdot \mathrm{year}^{-1}$ for nitrogen levels of 411 and $384 \mathrm{~kg} \cdot \mathrm{ha}^{-1}$, respectively. However, a considerable portion of forage production obtained by nitrogen addition occurred from stem production. The productions of green leaf blade dry matter, tiller density, leaf blade length and leaf blade index are all variables related to structural aspects and pasture quality, with all attaining their highest values at a mean nitrogen application level of $380 \mathrm{~kg}^{\mathrm{h}} \mathrm{a}^{-1}$.
\end{abstract}

\section{Keywords}

Forage Accumulation, Frequencies Cuts, Leaf Area Index, Tiller Density 


\section{Introduction}

In Brazil, the pastures lands have played a prominent role in the cow-calf, growing, and finishing phases of beef cattle production and milk production systems. However, grazing management often prioritizes animal performance without considering the recuperation capacity, and new tissue production of pasture without technical knowledge of plant behavior below the harvested or grazed component. This limitation has been responsible for the reduction in productivity and degradation pasture lands.

To define the most adequate pasture utilization strategies, it is necessary to know the behaviour and development of forage species in different edaphoclimatic cultivation conditions. Forage canopy structure, described by canopy height, forage mass, forage volumetric density, leaf area index, tiller population density and leaf to stem ratio characteristics can all affect grazing by the animals, as well as forage harvesting efficiency [1]-[4].

Piatã grass (Brachiaria brizantha cv. Piatã) originates in the Welega region of Ethiopia, and has been studied by Brazilian Agricultural Research Corporation for 16 years prior to this study. The plant presents a mean height between 0.85 and $1.10 \mathrm{~m}$, with rough upper face leaves and cutting edges with light hairs and thin stalks. This cultivar is adapted in the regions with annual precipitation greater than $800 \mathrm{~mm}$ and soils of average fertility. This grass is an option for pasture diversification due to its advantages of higher leaf accumulation, better soil tolerance and poorer drainage soils compared with Marandu grass [5], and greater resistance to leafhoppers than Xaraés cultivars [6].

Nitrogen is the most limiting component of pasture dry matter production. However, the response of tropical forage plants to nitrogen fertilisation is dependent on dose used and other factors related to the use of nitrogen, such as edaphoclimatic conditions, fertiliser type and forage conditions [7]. Due to the high cost of nitrogen fertilisers, it is important that cause and effect relationships are established for the application of nitrogen on the productive characteristics of grasses under different cultivation conditions.

In this context, it is important to consider the factors that may cause variations in the plant structure, principally those that are human-manipulated such as nitrogen fertilisation. The objective of this study was to evaluate the effect of increasing levels of nitrogen on the structural characteristics and forage production of Piatã grass under the edaphoclimatic conditions of the Brazil—-tropical savannah region.

\section{Methods}

The experiment was conducted at the Federal University of Mato Grosso at the Forage Experimental Campus in Rondonópolis-MT, Brazil, situated at geographical coordinates $16^{\circ} 28^{\prime} \mathrm{S}$ and $54^{\circ} 34^{\prime} \mathrm{W}$ at an altitude of $285 \mathrm{~m}$. Under the Köppen climate classification, the region is situated in a tropical savannah climatic zone, characterised by an irregular annual distribution of rainfall, with well-defined dry and wet seasons throughout the year. For the duration of the experiment, climatic data (Table 1) was collected from the local meteorological station situated $400 \mathrm{~m}$ from the experimental area.

About a year before the establishment of Piatã grass, were taken 20 soil samples in the experimental area at a depth of $0-20 \mathrm{~cm}$, the analyzes were $\mathrm{pH}$ in $\mathrm{CaCl}_{2}=3.5 ; \mathrm{Q}=0.8 \mathrm{mg} \cdot \mathrm{dm}^{-3} ; \mathrm{K}^{+}=15.0 \mathrm{mg} \cdot \mathrm{dm}^{-3} ; \mathrm{Ca}^{2+}=0: 35$ cmolc $\cdot \mathrm{dm}^{-3} ; \mathrm{Mg}^{2+}=0: 45 \mathrm{cmolc} \cdot \mathrm{dm}^{-3} ; \mathrm{Al}^{3+}=0.7 \mathrm{cmolc} \cdot \mathrm{dm}^{-3}$; organic matter $(\mathrm{OM})=13.0 \mathrm{~g} \cdot \mathrm{kg}^{-1}$; base saturation $=36.0 \%$.

After liming the results were: $\mathrm{pH}$ in $\mathrm{CaCl}_{2}=4.9 ; \mathrm{P}=1.7 \mathrm{mg} \cdot \mathrm{dm}^{-3} ; \mathrm{K}^{+}=29.0 \mathrm{mg} \cdot \mathrm{dm}^{-3} ; \mathrm{Ca}^{2+}=1.0 \mathrm{cmolc} \cdot \mathrm{dm}^{-3}$; $\mathrm{Mg}^{2+}=1.0 \mathrm{cmolc} \cdot \mathrm{dm}^{-3} ; \mathrm{H}+\mathrm{Al}^{3+}=2.4 \mathrm{cmolc} \cdot \mathrm{dm}^{-3} ; \mathrm{Al}^{3+}=0.1 \mathrm{cmolc} \cdot \mathrm{dm}^{-3} ;$ organic matter $(\mathrm{OM})=13.5 \mathrm{~g} \cdot \mathrm{kg}^{-1} ;$ sum of bases $=2.1 \mathrm{cmolc} \cdot \mathrm{dm}^{-3}$; cation exchange capacity $(\mathrm{CEC})=4.5 \mathrm{cmolc} \cdot \mathrm{dm}^{-3}$; base saturation $=46.0 \%$; clay $=400 \mathrm{~g} \cdot \mathrm{kg}^{-1}$; silt $=100,400 \mathrm{~g} \cdot \mathrm{kg}^{-1}$ and total area $=500,400 \mathrm{~g} \cdot \mathrm{kg}^{-1}$. Limestone quantity was obtained by the neutralisation method of exchangeable acids and elevated exchangeable $\mathrm{Ca}$ and $\mathrm{Mg}$ levels, applying the equivalent to $4400 \mathrm{~kg} \cdot \mathrm{ha}^{-1}$ of dolomitic limestone. Planting was made at the end of the wet season, on the 21/03/2007, with sowing in $32 \mathrm{~cm}$ lines and $\mathrm{P}_{2} \mathrm{O}_{5}$ (simple superphosphate) applied into the groove line at $100 \mathrm{~kg} \cdot \mathrm{ha}^{-1}$.

Twenty plots were used for the experiment, with each implanted into a $12 \mathrm{~m}^{2}$ area. On the 05 November 2007, the Piatã grass canopy was cut for the initiation of the experiment. The treatments were five levels of $\mathrm{N}$ applied at $0,125,250,375$ and $500 \mathrm{~kg} \cdot \mathrm{ha}^{-1}$, carried out using a completely randomised design, with four repetitions. Throughout the experiment $300 \mathrm{~kg} \cdot \mathrm{ha}^{-1} \mathrm{~K}_{2} \mathrm{O}$ in potassium chloride form was applied. The nitrogen (urea) and potassium fertiliser was divided into six levels (Table 2).

Forage samples were taken, every 35 days, in order to evaluate the forage mass per hectare, tillers morphologic composition and leaf area index. In each plot, one forage sample was selected by using a metal square $(1.0 \times$ 
Table 1. Mean monthly temperatures and rainfall registered for the experimental duration.

\begin{tabular}{ccccc}
\hline Month & $\begin{array}{c}\text { Minimum Temperature } \\
\left({ }^{\circ} \mathrm{C}\right)\end{array}$ & $\begin{array}{c}\text { Maximum Temperature } \\
\left({ }^{\circ} \mathrm{C}\right)\end{array}$ & $\begin{array}{c}\text { Mean Temperature } \\
\left({ }^{\circ} \mathrm{C}\right)\end{array}$ & $\begin{array}{c}\text { Rainfall } \\
\left(\mathrm{mm}^{-1} \cdot \mathrm{month}^{-1}\right)\end{array}$ \\
\hline November & 22.1 & 32.4 & 24.8 & 151 \\
December & 22.4 & 32.7 & 24.8 & 208 \\
January & 23.3 & 31.2 & 24.7 & 441 \\
February & 22.4 & 31.4 & 24.6 & 302 \\
March & 21.8 & 32.0 & 24.4 & 159 \\
April & 20.3 & 31.5 & 23.6 & 271 \\
\hline
\end{tabular}

Table 2. Intervals between cuts and distribution of nitrogen fertiliser $\left(\mathrm{kg} \cdot \mathrm{ha}^{-1}\right)$ throughout the experiment.

\begin{tabular}{cccccccc}
\hline & \multicolumn{5}{c}{ Cuts } & $4^{\circ}$ & $5^{\circ}$ \\
\cline { 2 - 7 } Fertilisation kg/ha & Uniformisation & $1^{\circ}$ & $2^{\circ}$ & $18 / 02 / 08$ & $24 / 03 / 08$ & $28 / 04 / 08$ \\
\cline { 2 - 7 } & $05 / 11 / 07$ & $10 / 12 / 07$ & $14 / 01 / 08$ & 0 & 0 & 0 & 20.83 \\
125 & 0 & 0 & 0 & 20.83 & 41.66 & 62.50 \\
250 & 20.83 & 20.83 & 20.83 & 41.66 & 41.66 & 46 & 83.53 \\
375 & 41.66 & 41.66 & 62.50 & 62.50 & 62.50 & 83.33 & 83.33 \\
500 & 62.50 & 62.50 & 83.33 & 83.33 & & & \\
\hline
\end{tabular}

$0.6 \mathrm{~m}$ ) and cut at $15 \mathrm{~cm}$ above the soil.

Before harvest, Piatã grass canopy from all plots were measured for height and tillers density. Canopy height was determined using a PVC ruler pipe graduated in $\mathrm{cm}$, measuring 20 random points per experimental plots. To evaluate tillers density, metal square $(0.15 \times 1.00 \mathrm{~m})$ were used to allocate of a local representative pasture for the mean plant height of each parcel.

Canopy height was then determined using a PVC ruler pipe graduated in $\mathrm{cm}$, measuring 20 random points per experimental unit. Each point was measured by obtaining the mean height of plants for each ruler. The leaf blade length was measured by the sum of all lengths of each tiller divided by the number of leaves per tiller, with these findings determined using a millimetre-graded ruler at each evaluation cycle.

The total dry matter availability of Piatã grass was determined by direct sampling using a $1.00 \times 0.60 \mathrm{~m}$ quadrate. Nineteen quadrates were placed in sites representing mean plant height, one sample per parcel. All forage contained in quadrates was cut $15 \mathrm{~cm}$ above soil level. After cutting, samples were sent to the laboratory for determinations of forage accumulation, tiller morphological composition and leaf area index.

Following weighing, each parcel sample was divided into two subsamples. The first subsample was subjected to plant component (leaf blade, stem and senescent material) weighing, and then dried in a fan-forced oven at $79^{\circ} \mathrm{C}$ for $72 \mathrm{~h}$ [8]. The other subsample was used for the determination of leaf area index, following the methodology described by [9]. In this method, intact leaf blade samples were completely separated from the base into fractions of $10 \mathrm{~cm}$, totaling 150 pieces. Following this, each fraction width was measured and values added. The formula described below was used to obtain the leaf area index (LAI) measurements of each parcel.

$$
\mathrm{LAI}=\left\{\left[(\mathrm{GLBW} / \mathrm{QA}) \times\left(\mathrm{SW} \times 100 / P_{150}\right)\right] / 10^{6}\right\}
$$

- $\mathrm{GLBW}=$ green leaf blade weight (g), obtained by the quadrate method;

- $\mathrm{SW}=$ sum of width of $10 \mathrm{~cm}$ fractions $(\mathrm{n}=150)$;

- $P_{150}=$ weight of 150 fractions (g);

- $\mathrm{QA}=$ quadrat area utilised $(0.15 \times 1 \mathrm{~m})$.

The experimental variables were: dry matter production (total, leaf, stem and dead material), plant height, tiller density, final leaf blade length and leaf area index; the variables were analysed by means of a linear mixed model. The model considered the fixed effects of cutting and fertilisation and the random residual effects of 
parcel and ambient temperature. The effect of fertilisation was initially modelled by an ordinary quadratic polynomial and when the quadratic coefficient was not significant $(\mathrm{P}<0.05)$, a more simple model was used for evaluation. The random parcel effect was modelled by a heterogeneous first order auto-regressive (ARH(1)) covariance structure. The parameters of these matrices were estimated by the Restricted Maximum Likelihood (REML) method, adopted by convergence criteria from the default MIXED procedure from [10].

The significance of included effects included in the statistical models was evaluated by the F-test at a $1 \%$ significance level. The $\left(\mathrm{R}^{2}\right)$ coefficient was determined by obtaining the square of the resulting correlation between the estimated value and the observed value. The intercepts of the regression equations were obtained by adding the overall intercept to the mean of the solutions for the cutting equations. The quadratic and the linear regression coefficient solutions were obtained directly.

\section{Results and Discussion}

Quadratic effect was verified ( $<$ 0.01) for the effect of nitrogen dose on canopy height (Figure 1), with the maximum value estimated at $60.6 \mathrm{~cm}$ when the nitrogen dose was $500 \mathrm{~kg} \cdot \mathrm{ha}^{-1}$. For tropical grasses, as forage canopy height increases a strong correlation between stem elongation and stem to leaf ratio is observed [11] [12]. This fact was also observed in this experiment, with increases in elongation observed when the plant reached its critical leaf area index. Growth beyond the forage nutritive value compromises the nutritional value and modifies the structure of pasture, thus affecting animal consumption of forage [13].

Quadratic effect was also verified $(\mathrm{P}<0.01)$ for nitrogen fertilisation affecting the final leaf blade length in the wet season (Figure 2), with the maximum value estimated at $198 \mathrm{~mm} \cdot \mathrm{leaf}^{-1}$ at a nitrogen dose of $440 \mathrm{~kg} \cdot \mathrm{ha}^{-1}$, which resulted in an increase by 31\% compared to the control treatment (no fertiliser added).

In study with Xaraés grass cut at $22 \mathrm{~cm}$ above soil level [14] subjected to nitrogen fertilisation and found a mean maximum leaf blade length of $271 \mathrm{~mm}$ per leaf at a nitrogen dose of $344 \mathrm{~kg} \cdot \mathrm{ha}^{-1}$. The lower lengths observed in the present experiment can be attributed to the lower residual height used and to the different genetics of the grass species used. Final leaf blade length is a plant characteristic proportional to the foliage intensity, considered as a morphologic strategy of plants for grazing and cutting tolerance [1].

Quadratic effect was observed for the effect $(\mathrm{P}<0.01)$ of nitrogen dose on tiller population density (Figure 3), with the estimated maximum value being 955 tillers $\cdot \mathrm{m}^{-2}$ at a nitrogen dose of $357 \mathrm{~kg} \cdot \mathrm{ha}^{-1}$. Nitrogen had a strong influence on tiller density, registering a 54\% increase at $357 \mathrm{~kg}$ of nitrogen applied per ha, compared with 628 tillers $\cdot \mathrm{m}^{-2}$ when no nitrogen fertiliser was applied. The reduction in tiller population at levels greater than 357 $\mathrm{kg} \cdot \mathrm{ha}^{-1}$ was associated with a fixed cutting frequency at 35 day intervals in this study. These conditions proportionally increased the leaf blade and stem growth, consequently shading lower tiller leaves closer to the base. This situation ratified the importance of managing the cutting or grazing frequency considering the quantity of applied nitrogen.

When evaluating the effect of nitrogen levels between 0 and $500 \mathrm{~kg} \cdot \mathrm{ha}^{-1}$, [14] found a maximum value of 772 tillers $\cdot \mathrm{m}^{-2}$ in Brachiaria brizantha cv. Xaraés grass fertilized with nitrogen at a level of $270 \mathrm{~kg} \cdot \mathrm{ha}^{-1}$. As the meteorological conditions of the area were similar in both experiments, the differences observed can be attributed to the effects of different years, and mostly, cultivar species. Between the factors that contribute to pasture

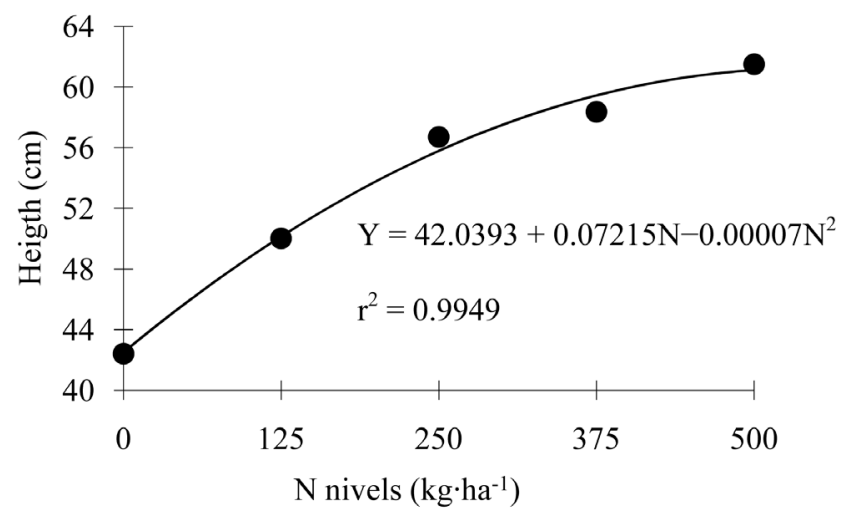

Figure 1. Height of Piatã grass subjected to nitrogen $(\mathrm{N})$ levels. 


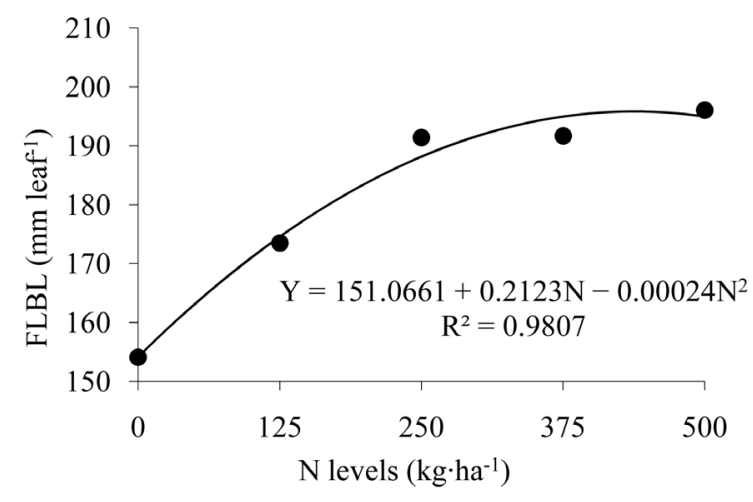

Figure 2. Final leaf blade length (FLBL) of Piatã grass subjected to nitrogen $(\mathrm{N})$ levels.

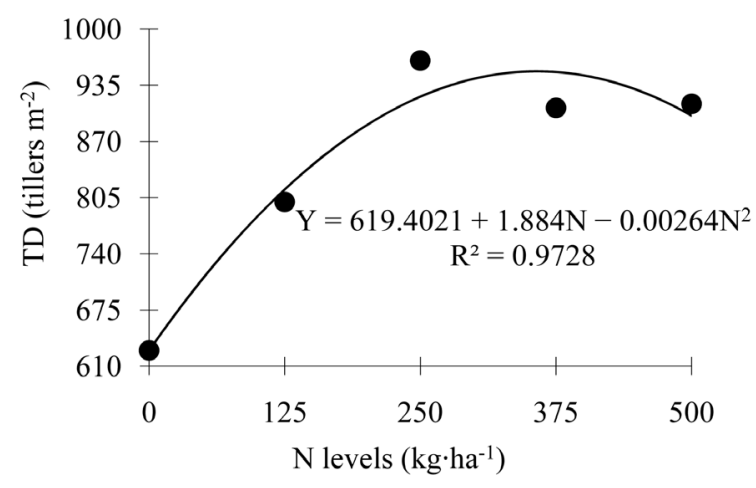

Figure 3. Piatã grass tiller density (TD) subjected to nitrogen $(\mathrm{N})$ levels.

tillering characteristics, nitrogen fertilisation and residual height are the most influential to this variable.

Quadratic effect was observed for the effect $(\mathrm{P}<0.01)$ of nitrogen dose on leaf blade index (Figure 4), with the maximum value estimated as 4.77 at a nitrogen levels of $385 \mathrm{~kg} \cdot \mathrm{ha}^{-1}$, which resulted in a $167 \%$ increased when compared to grass receiving no nitrogen fertilisation. These results can be related to the final leaf blade lengths observed in Figure 2, the tiller density observed in Figure 3 and the leaf blade accumulation rate with nitrogen addition. Leaf area index, light interception and canopy height are the variables related to the quantitative and qualitative aspects of forage accumulation and have been utilised as grazing management parameters in both continuous and rotational stocking systems [4]-[11].

In [14] study with Xaraés grass, the maximum leaf area index found was 6.9 at a nitrogen dose of $250 \mathrm{~kg} \cdot \mathrm{ha}^{-1}$, superior to the value found in this study. Fertilizing pasture with nitrogen should have special attention primarily given to grazing management, followed by leaf area index behaviour, as high leaf area indices can result in a lack of, or negative forage accumulation, by favouring the process of senescence as opposed to plant growth.

Quadratic effect was found for the effect of nitrogen fertilisation $(\mathrm{P}<0.01)$ on green leaf blade dry matter production (Figure 5), with an estimated maximum value of $11,548 \mathrm{~kg} \cdot \mathrm{ha}^{-1} \cdot \mathrm{year}^{-1}$ at a nitrogen dose of 384 $\mathrm{kg} \cdot \mathrm{ha}^{-1}$, increasing in value by $131 \%$ when compared with the grass which received no nitrogen fertilisation. Maximum values of leaf area index and leaf blade production were found at similar levels of nitrogen, constituting the presence of a relationship between these two variables.

To concentrate greater tissue proportions with improved chemical composition and digestibility and showing less thickening and lignin deposition in the cell wall with advanced age [15] [16], leaf blade production is prioritised in cutting and grazing management in comparison to stems. When comparing Piatã, Marandu and Xaraés grasses in pasture systems, [17] verified that the leaf blade availability was expressed by the leaf to stem and leaf to dead material ratios, with these important for nutritive value and animal weight gain control, with the highest individual weight gain observed in Piatã grass.

Stem dry matter production was influenced quadratically $(\mathrm{P}<0.01$ ) by applied levels of nitrogen (Figure 6). 


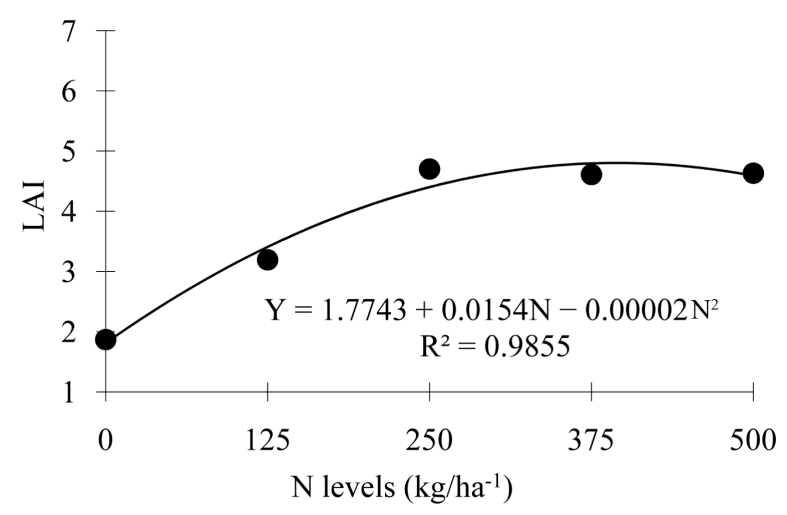

Figure 4. Leaf area index (LAI) of Piatã grass subjected to nitrogen $(\mathrm{N})$ levels.

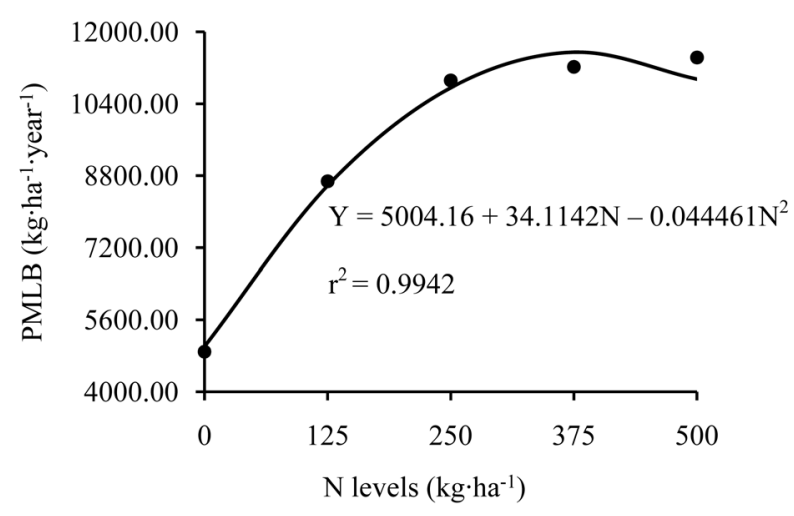

Figure 5. Production of dry mass of leaf blades (PMLB) of grass Piatã subjected to nitrogen $(\mathrm{N})$ levels.

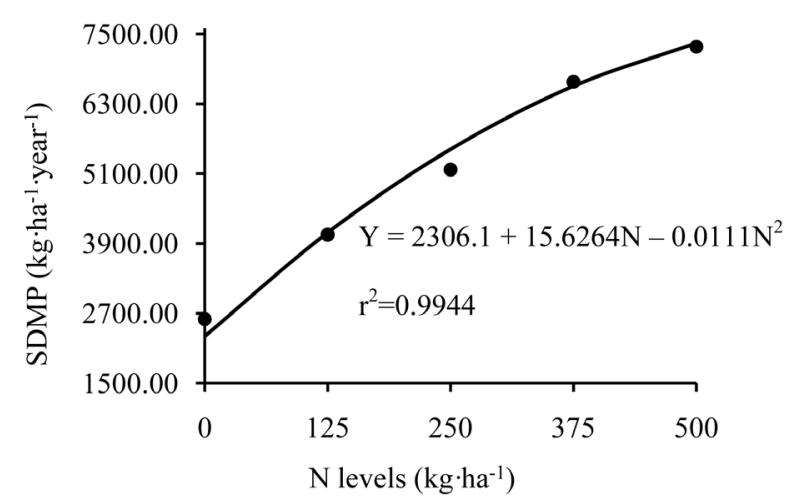

Figure 6. Behaviour of stem dry matter production (SDMP) for Piatã grass subjected to nitrogen $(\mathrm{N})$ levels.

The maximum value was estimated by a regression equation to be $7344 \mathrm{~kg}$ stem DM per ha per year at a nitrogen dose of $504 \mathrm{~kg} \cdot \mathrm{ha}^{-1}$. The highest nitrogen dose used in this experiment resulted in a $218 \%$ increase in stem DM production compared to the value of $2306.1 \mathrm{~kg} \cdot \mathrm{ha}^{-1} \cdot \mathrm{year}^{-1}$ in grass parcels without nitrogen fertilisation. This result verified that fixing the cutting frequency to 35 days added to the favorable conditions of precipitation and temperature for the experimental duration (Table 1) along with the fertilisation, which contributed to favour strong stem growth and an increased stem to leaf ratio.

[18] evaluated Marandu grass cultivated in a degraded pasture area and found an increase of only $76 \%$ in stem dry matter production when $300 \mathrm{~kg}$ of nitrogen was applied per hectare compared to grasses without nitrogen 
fertilisation. The low accumulation of stem dry matter in forage plants when nitrogen fertilisation was absent can be related to the decreased stem elongation and low tillering levels [9].

When compared to leaf blades, stems showed a greater proportion of degradation resistant tissue such as sclerenchyma and parenchyma, which when combined with advanced age resulted in intense cell wall thickening and lignin deposition with resulting rapid reduction in nutritive value [15] [16]. These characteristics are associated with elevated canopy height (Figure 1) and stem production (Figure 6) observed with increased nitrogen levels, promoting rapid alteration of the pasture structure and affecting animal consumption.

Quadratic effect was observed for the effect $(\mathrm{P}<0.01)$ of nitrogen dose on the content of dead material dry matter (Figure 7). The regression equation obtained gave estimated minimum and maximum dead DM values of 1070 and $1280 \mathrm{~kg} \cdot \mathrm{ha}^{-1}$ per year at nitrogen levels of zero and $258 \mathrm{~kg} \cdot \mathrm{ha}^{-1}$, respectively. Together with stem production, dead material contributed to reduce the nutritive value and animal forage consumption (Euclides et al., 2009).

Quadratic effect was also observed $(\mathrm{P}<0.01)$ for the total dry matter production at different levels of nitrogen (Figure 8), with an estimated maximum value of $19,253 \mathrm{~kg} \cdot \mathrm{ha}^{-1} \mathrm{DM}$ at a nitrogen dose of $411 \mathrm{~kg} \cdot \mathrm{ha}^{-1}$ resulting in an increase of $118 \%$ compared to grass receiving no nitrogen fertilisation. This experiment can be compared with various findings of Brachiaria brizantha demonstrating a greater response to nitrogen fertiliser [19]-[21]. This information should be viewed with caution however, because this research showed a high percentage of dead material and stem production with inflorescence which may incur animal production losses, particularly when nitrogen is used to accelerate tissue flow.

Considering that the green dry matter production was $16367.30 \mathrm{~kg} \cdot \mathrm{ha}^{-1}$ when $250 \mathrm{~kg} \cdot \mathrm{ha}^{-1}$ nitrogen was added, $300 \mathrm{~kg}$ steers consuming pasture $2.5 \%$ of their body weight and a grazing efficiency of $60 \%$ render it possible to maintain a stocking rate equivalent to 7.5 animals per hectare for the 175 experimental days.

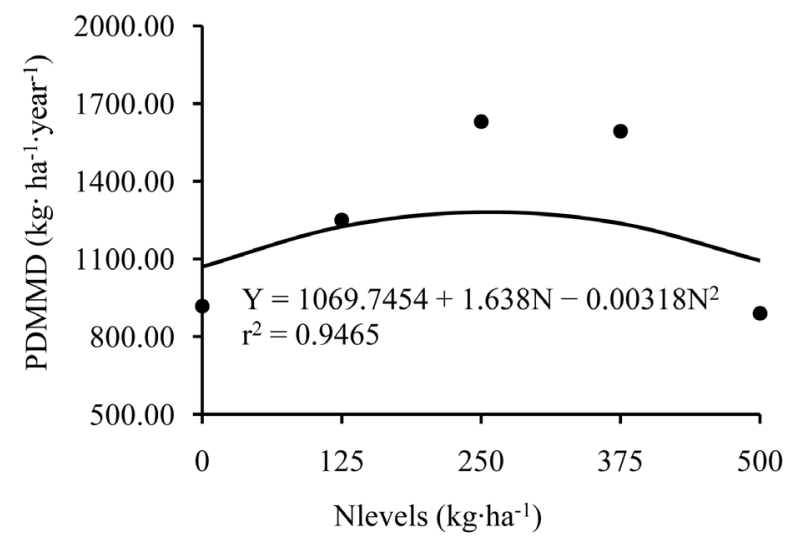

Figure 7. Production of dead material dry matter (PDMMD) for Piatã grass subjected to nitrogen $(\mathrm{N})$ levels.

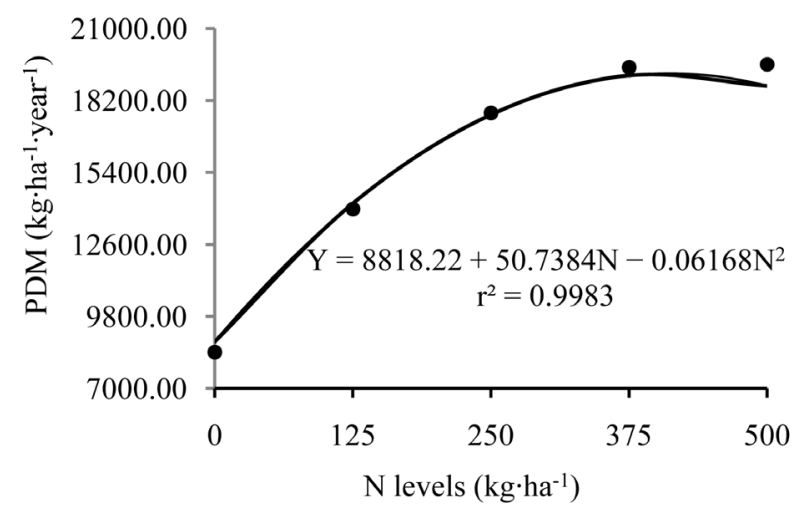

Figure 8. Production of dry matter (PDM) of Piatã grass subjected to nitrogen $(\mathrm{N})$ levels. 


\section{Conclusions}

The productions of green leaf blade dry matter, tiller density, leaf blade length and leaf blade index are all variables related to structural aspects and pasture quality, with all attaining their highest values at a mean nitrogen application level of $380 \mathrm{~kg} \cdot \mathrm{ha}^{-1}$.

To optimise forage production and pasture quality of Piatã grass, it is necessary to adjust cutting and regrowth days as a function of the quantity of nitrogen applied during fertilisation.

Piatã grass showed high dry matter production, good regrowth and soil cover capacity, making it a good alternative for pasture area diversification.

\section{Acknowledgements}

Foundation for Research Support of the State of Mato Grosso.

\section{References}

[1] Lemaire, G. and Chapman, D. (1996) Tissue Flows in Grazed Plant Communities. In: Hodgson, J. and Illius, A.W., Eds., The Ecology and Management of Grazing Systems, CAB International, London, 3-36.

[2] Sollenberger, L.E. and Burns, J.C. (2001) Canopy Characteristics, Ingestive Behaviour and Herbage Intake in Cultivated Tropical Grasslands. International Grassland Congress, 19, 321-327.

[3] Zanine, A.M., Nascimento, J.D., Santos, M.E.R., et al. (2011) Structural Characteristics and Accumulation of Forage Grass in Tanzania-Grazed Rotary. Brazilian Journal of Animal Science, 40, 2364-2373.

[4] Zanine, A.M., Nascimento, J.D., Sousa, B.M.L., et al. (2013) Tillering Dynamics in Guinea Grass Pastures Subjected to Management Strategies under Rotational Grazing. Brazilian Journal of Animal Science, 42, 155-161.

[5] Caetano, L.P.S., Dias-Filho, M.B., et al. (2008) Responses of Six Brachiaria spp. Accessions to Root Zone Flooding. Brazilian Journal of Animal Science, 37, 795-801.

[6] Valle, C.B., Euclides, V.P.B., Pereira, J.M., et al. (2013) O capim-xaraés Brachiaria brizantha cv. Xaraés) na Diversificação das Pastagens de Braquiárias. Embrapa Gado de Corte, Campo Grande, 149, 36 p.

[7] Ferreira, D.J. and Zanine, A.M. (2014) Challenges Facing Pasture in the Context of Agricultural Multifunctionality in Brazil. American Journal of Experimental Agriculture, 4, 1793-1811. http://dx.doi.org/10.9734/AJEA/2014/12597

[8] Silva, D.J. and Queiroz, A.C. (2002) Análise de Alimentos (Métodos Químicos e Biológicos). 3rd Edition, Imprensa. Universitária da UFV, Viçosa, 235 p.

[9] Alexandrino, E., Nascimento, J.D., Regazzi, A.J., et al. (2005) Morphogenic and Structural Traits of Brachiaria brizantha cv. Marandu Submitted to Different Levels of Nitrogen and Frequency Harvest. Acta Scientiarum, 27, 7-14.

[10] Statistical Analysis System (2001) User’s Guide: Statistics, Version 8.2. SAS Institute, NC, USA.

[11] Da Silva, S.C. and Nascimento, J.D. (2007) Advances in Research on Tropical Forages in Pastures: Morphological and Physiological Characteristics and Grazing Management. Brazilian Journal of Animal Science, 36, 121-138.

[12] Pena, C.K., Nascimento, J.D., Silva, S.C., et al. (2009) Características Morfogênicas, Estruturais e Acúmulo de Forragem do Capim-Tanzânia Submetido a duas alturas e Três Intervalos de Corte. Brazilian Journal of Animal Science, 38, 2127-2136.

[13] Santos, E.M., Zanine, A.M., Parente, H.N., de Jesus Ferreira, D., de Almeida, F.Q. and Cecon, P.R. (2006) Comportamento Ingestivo de Eqüinos em Pastagens de Grama Batatais (Paspalum notatum) e braquiarinha (Brachiaria decumbens) na Região Centro-Oeste do Brasil. Ciência Rural, 36, 1565-1569. http://dx.doi.org/10.1590/S0103-84782006000500035

[14] Cabral, W.B., Souza, A.L., Alexandrino, E., Toral, F.L.B., dos Santos, J.N. and de Carvalho, M.V.P. (2012) Structural Characteristics and Agronomic Traits of Brachiaria brizantha cv. Xaraés Subjected to Nitrogen Levels. Brazilian Journal of Animal Science, 41, 846-855.

[15] Paciullo, D.S.C., Gomide, J.A., Silva, E.A.M., Queiroz, D.S. and Gomide, C.A.M. (2002) Anatomical Traits of Leaf Blade and Stem of Tropical Forage Grasses, According to Level of Insertion on the Grass Tiller, Age and Season of Growth. Brazilian Journal of Animal Science, 31, 890-899.

[16] Paciullo, D.S.C., Gomide, J.A., Silva, E.A.M., et al. (2002) In Vitro Digestion of Leaf Blade and Stem Tissues of Tropical Forage Grasses According to Stages of Development. Brazilian Journal of Animal Science, 31, 900-907.

[17] Euclides, V.P.B., Macedo, M.C.M., Valle, C.B., dos Santos Difante, G., Barbosa, R.A. and Cacere, E.R. (2009) Forage Nutritive Value and Animal Production in Brachiaria brizantha Pastures. Pesquisa Agropecuária Brasileira, 44, 98106. http://dx.doi.org/10.1590/S0100-204X2009000100014 
[18] Silva, D.R.G. (2007) Structural Characteristics and Nitrogen Fertilisation Efficiency of Marandugrass Pasture in Moderate Stage of Degradation under Nitrogen Rates and Sources. Dissertation (MSc in Soil Science), Federal University of Lavras, Lavras, 89.

[19] Costa, K.A.P., Oliveira, I.P., Faquin, V., et al. (2009) Dry Mass Production and Nitrogen Nutritional Value of Brachiaria brizantha (A. Rich) Stapf Cultivars under Nitrogen Levels. Ciência Agrotécnica, 33, 1578-1585.

[20] De Bona, F.D. and Monteiro, F.A. (2010) Marandu Palisadegrass Growth under Nitrogen and Sulphur for Replacing Signal Grass in Degraded Tropical Pasture. Scientia Agricola, 67, 570-578. http://dx.doi.org/10.1590/S0103-90162010000500011

[21] Dupas, E., Buzetti, S., Sarto, A.L., Hernandez, F.B.T. and Bergamaschine, A.F. (2010) Dry Matter Yield and Nutritional Value of Marandu Grass under Nitrogen Fertilisation and Irrigation in Cerrado in São Paulo. Brazilian Journal of Animal Science, 39, 2598-2603. 